\title{
Contrasting effects of necrotrophic and biotrophic plant pathogens on the aphid Aphis fabae
}

Article

Accepted Version

Al-Naemi, F. and Hatcher, P. (2013) Contrasting effects of necrotrophic and biotrophic plant pathogens on the aphid Aphis fabae. Entomologia Experimentalis Et Applicata, 148 (3). pp. 234-245. ISSN 0013-8703 doi:

https://doi.org/10.1111/eea.12091 Available at https://centaur.reading.ac.uk/33136/

It is advisable to refer to the publisher's version if you intend to cite from the work. See Guidance on citing.

To link to this article DOI: http://dx.doi.org/10.1111/eea.12091

Publisher: Wiley

All outputs in CentAUR are protected by Intellectual Property Rights law, including copyright law. Copyright and IPR is retained by the creators or other copyright holders. Terms and conditions for use of this material are defined in the End User Agreement.

www.reading.ac.uk/centaur 
Central Archive at the University of Reading

Reading's research outputs online 


\section{Contrasting effects of necrotrophic and biotrophic plant}

\section{pathogens on the aphid Aphis fabae}

\section{Fatima Al-Naemi* \& Paul E Hatcher}

School of Biological Sciences, University of Reading, Reading, RG6 6AS, UK

* Current address: Qatar University, Department of Biological and Environmental Sciences, Doha, Qatar, PO Box 2713

\section{Corresponding author:}

P E Hatcher, School of Biological Sciences, University of Reading, Reading, RG6 6AS, UK, e-mail: p.e.hatcher@ reading.ac.uk 


\section{Abstract}

Phytophagous insects have to contend with a wide variation in food quality brought about by a variety of factors intrinsic and extrinsic to the plant. One of the most important factors is infection by plant pathogenic fungi. Necrotrophic and biotrophic plant pathogenic fungi may have contrasting effects on insect herbivores due to their different infection mechanisms and induction of different resistance pathways, although this has been little studied and there has been no study of their combined effect. We studied the effect of the biotrophic rust fungus Uromyces viciae-fabae (Pers.) Schroet (Basidiomycota: Uredinales: Pucciniaceae) and the necrotrophic fungus Botrytis cinerea Pers. (Ascomycota: Helotiales: Sclerotiniaceae) singly and together on the performance of the aphid Aphis fabae Scop. (Hemiptera: Aphididae) on Vicia faba (L.) (Fabaceae). Alone, botrytis had an inhibitory effect on individual A. fabae development, survival and fecundity, while rust infection consistently enhanced individual aphids' performance. These effects varied in linear relation to lesion or pustule density. However, whole-plant infection by either pathogen resulted in a smaller aphid population of smaller aphids than on uninfected plants, indicating a lowering of aphid carrying capacity with infection. When both fungi were applied simultaneously to a leaf they generally cancelled the effect of each other out, resulting in most performance parameters being similar to the controls, although fecundity was reduced. However, sequential plant infection (pathogens applied five days apart) led to a 70\% decrease in fecundity and 50\% reduction in intrinsic rate of increase. The application of rust before botrytis had a greater inhibitory effect on aphids than applying botrytis before rust. Rust infection increased leaf total nitrogen concentration by $30 \%$ while infection by botrytis with or without rust led to a $38 \%$ decrease. The aphids' responses to the two plant pathogens individually is consistent with the alteration in plant nutrient content by infection and also the induction of different plant defence 
pathways and the possible cross-talk between them. This is the first demonstration of the complex effects of the dual infection of a plant by contrasting pathogens on insect herbivores.

Key words: Vicia faba, Botrytis cinerea, Uromyces viciae-fabae, tripartite interactions, induced resistance

\section{Introduction}

An insect herbivore not only has to contend with the direct effects of a variable and often poor-quality food source (Mattson, 1980), the vagaries of climate and a range of parasites and predators, but also indirect effects caused by other organisms exploiting this food resource (Hatcher, 1995; Rostás et al., 2003; Stout et al., 2006). One of the most important such groups of organisms are plant pathogenic fungi (Hawksworth, 1991). These can cause a range of effects to their host plants: increasing or decreasing nutrient levels in infected leaves or uninfected leaves on the same plant, altering the concentration of defensive chemicals, and up- or down-regulating an array of resistance pathways (Hatcher et al., 2004; Bostock, 2005; Stout et al., 2006). These changes to the plant can lead to insect herbivores having altered fitness when feeding on a plant infected by a pathogenic fungus (Hatcher, 1995).

Although there are now several well-studied model systems in which tripartite insectplant-plant pathogen interactions have been elucidated (Hatcher, 1995; Rostás et al., 2003; Stout et al., 2006) most of these have only considered the interaction between one insect and one plant pathogen. However, in an attempt to bridge the gap between reductionist studies of pair-wise interactions and the holistic study of food webs and communities there is a need to study more complex consumer interactions on plants. It is difficult to predict the outcome of 
single insect-plant-fungus interactions (Hatcher, 1995), and more complex systems will be harder still to predict without some guiding empirical studies of these more complex interactions.

Recent studies on the defences induced by necrotrophic and biotrophic plant pathogens and the cross-talk between these pathways and the induced defence pathways affecting insect herbivores suggest that these two types of fungal pathogen may affect insect herbivores in a contrasting fashion. For example, effective defence against biotrophic pathogens is largely due to programmed cell death (the hypersensitive response) and the associated activation of defence responses regulated by the salicylic acid (SA)-dependent pathway (Glazebrook, 2005; van Loon et al., 2006), whilst necrotrophic pathogens benefit from cell death, and thus activation of this pathway would only facilitate their infection (van Loon et al., 2006). Instead, necrotrophic pathogens may induce activation of jasmonic-acid (JA) and ethylene (ET)-dependent defence signalling (Glazebrook, 2005), with SA-induced pathways only becoming important later if the necrotroph starts to behave as a hemi-biotroph (van Loon et al., 2006). Similarly, insects with different modes of feeding may induce different pathways, with chewers often inducing the JA-dependent defence pathway, and sucking insects such as aphids the SA-dependent pathways (Walling, 2008; Thaler et al., 2010).

The SA and JA-dependent pathways do not exist in isolation; rather there is cross-talk between them, with activation of the SA-dependent pathway often leading to a downregulation of the JA-dependent pathway and vice-versa (Bostock, 2005; van Loon et al., 2006; Robert-Seilaniantz et al., 2011), and thus we may expect the interaction between a necrotrophic pathogen and a sucking insect to be different than that between a biotrophic pathogen and a sucking insect on the same plant, but will lead to unexplored complications if the insect is exposed to several different pathogens simultaneously. 
The broad bean, Vicia faba (L.) (Fabaceae) is attacked by a range of pests in Europe; among the most important are the aphid Aphis fabae Scop. (Hemiptera:Aphididae) (Banks \& Macaulay, 1964), the necrotrophic pathogen Botrytis cinerea Pers. (Ascomycota: Helotiales: Sclerotiniaceae) (Davidson et al., 2004) and the biotrophic rust Uromyces viciae-fabae (Pers.) Schroet (Basidiomycota: Uredinales: Pucciniaceae) (Gaunt, 1983). Although B. cinerea often infects plants early in the season and $U$. viciae-fabae infects later in the year, both often occur together on the plant at a time when A. fabae is also present. Alone, both $U$. viciaefabae and B. cinerea have been reported to increase aphid performance (Zebitz, 1988; Prüter \& Zebitz, 1991; Zebitz \& Kehlenbeck, 1991) most likely through increased mobilisation of carbohydrates and nitrogen through the plant and into infected leaves (Thrower \& Thrower, 1966; Farrar \& Lewis, 1987; van Kan, 2006; Choquer et al., 2007). However, we would predict from induced resistance studies that $B$. cinerea would enhance aphid performance by inducing the JA pathway and thus down-regulating the SA pathway (Bostock, 2005; RobertSeilaniantz et al., 2011), while U. viciae-fabae would decrease aphid performance by costimulating the SA-dependent induced resistance pathway. This is assuming that, as has been found for many species of aphids, A. fabae in this system is sensitive to the resistance induced by the SA pathway (Walling, 2008; Thaler et al., 2010) The effect of dual infection on A. fabae is hard to predict, partly because of the lack of a predictive framework for such interactions (Thaler et al., 2010) and also due to the unknown effect of resource depletion caused by dual infection (e.g. Grueber \& Dixon, 1988), but we would expect it to depend on the order of infection and thus the order of stimulation or inhibition of defence responses.

In this paper we first quantify the effect on $A$. fabae of individual infections of $V$. faba with $B$. cinerea and $U$. viciae-fabae, and then report the first experiments to determine the effect of concurrent or sequential infection of the two contrasting plant pathogens on the performance of the aphid. 


\section{Materials and methods}

Experimental organisms

All experiments and plant rearing were carried out in a constant environment (CE) room at the University of Reading at $18-20^{\circ} \mathrm{C}$ and L16:D8 photoperiod.

Botrytis cinerea was obtained from a culture (originally isolated from the University of Reading Campus, Whiteknights, Reading, UK), maintained at the University of Reading, subcultured every 10 days on $4 \%$ malt extract agar and potato dextrose agar and incubated at $20 \pm 1^{\circ} \mathrm{C}$ in constant darkness. Conidia were harvested from 16-day-old cultures by flooding the plate with sterile distilled water and dislodging the conidia with a sterile rod, and subsequent filtration through four layers of cheesecloth to remove mycelial debris. A $0.1 \mathrm{ml}$ suspension of a $1 \times 10^{4}$ conidia $\mathrm{ml}^{-1}$ inoculum was applied to the adaxial surface of each leaflet with a paint brush. After 30 min the plants were enclosed in polythene bags containing a saturated atmosphere at $20 \pm 1^{\circ} \mathrm{C}$ for $48 \mathrm{hrs}$ to allow spore germination before aphids were confined in a clip cage on the leaves. $0.1 \mathrm{ml}$ sterilised distilled water was used as a control.

Uromyces viciae-fabae (originally isolated from the University of Reading Campus, Whiteknights, Reading, UK), was cultured permanently on $V . f a b a$ at the University of Reading in a CE room at $20^{\circ} \mathrm{C}$ and L16:D8 photoperiod. Uredospores were brushed from plants and stored at $-20^{\circ} \mathrm{C}$ until use. Leaflets were evenly sprayed with a $1 \times 10^{5} \mathrm{ml}^{-1}$ suspension of spores in distilled water using a modeller's airbrush. The inoculated plants were incubated for $48 \mathrm{hrs}$ in a saturated atmosphere in polythene bags in the CE room to allow germination and infection. In the CE room $U$. viciae-fabae usually showed first signs 
of infection after 6 to 7 days and sporulated after 10 days. Plants were challenged with aphids 10 days after inoculation.

Black bean aphids, Aphis fabae, were obtained from a population maintained at the University of Reading (originating from aphids collected from the wild in Reading, UK). This population was reared on $V$. faba L. cv 'The Sutton' at $18-20^{\circ} \mathrm{C}$ and L16:D8 photoperiod in 51x69x69 $\mathrm{cm}$ perspex cages, with fan-assisted air circulation.

Effect of one fungus on individual aphids

Individual seeds of $V$. faba (cv 'The Sutton', Thompson and Morgan, Ipswich, UK - this cultivar was used in all experiments) were planted in 9-cm diameter pots of John Innes II compost. The plants were selected for treatment when five true leaves had appeared. For each fungus 60 plants were used, split equally between infected and uninfected plants. To measure local effects of infection, a leaflet on leaf 3 ('old') was infected with $B$. cinerea or $U$. viciae-fabae as above, and 2 or 10 days respectively after inoculation an aphid was placed in a clip cage on this infected leaflet. This time difference was selected so that the aphid encountered each pathogen at the same stage of development, i.e. sporulating pustules. Aphids were also caged on an adjacent uninfected old (leaf 3) leaflet and an uninfected new leaflet (leaf 5) on that plant to test if infection led to systemic effects in leaflets close to the source of infection, or newer, more distant leaflets. Aphids were also caged on an old (leaf 3) and young (leaf 5) leaflet on uninfected plants as a control.

Aphids were caged using 20 mm diameter perspex clip cages (Van Emden, 1972), supported so that leaflets maintained their normal position. First instar nymphs were transferred to the clip cages (one per cage) using a moistened paintbrush as soon as they were born. They were then kept on the leaf until they had matured and produced offspring for 10 
days. The speed of aphid development was calculated as maturation time: the time in days between birth of an aphid and the birth of its first offspring. The mean relative growth rate (MRGR) of individual aphids in clip cages was determined after measuring the fresh weights of first-instar nymphs at the beginning and after 4 days of the experimental period on an electrical microbalance (Sartorius Supermicro S4), and MRGR $(\mu \mathrm{g} / \mu \mathrm{g} / \mathrm{day})$ calculated as $\left(\log \mathrm{W}_{2}-\log \mathrm{W}_{1}\right) /\left(\mathrm{t}_{2}-\mathrm{t}_{1}\right)$, where $\mathrm{W}_{1}$ is weight at the first measurement $\left(\mathrm{t}_{1}\right)$ and $\mathrm{W}_{2}$ weight at the second measurement $\left(\mathrm{t}_{2}\right)$. MRGR provides a measure of performance of the aphid which is likely to be directly related to the nutrition of the aphid, and independent of maternal effects (Van Emden, 1969; Wojciechowicz-Zytho \& Van Emden, 1995), and is a measure of the growth of the aphid relative to its weight. The intrinsic rate of increase $\left(r_{m}\right)$ (Wyatt \& White, 1977) was calculated by recoding the number of nymphs produced by each individual during their first 10 days of reproduction (nymphs were removed from clip-cages as they were produced), using the formula $r_{m}=[c \ln (M d)] / D$, where $M d$ is the number of nymphs produced by the adult in the first 10 days (D) of reproduction after the adult moult, the constant (c) has the value of 0.738 and is an approximation of the proportion of the total fecundity produced by a female in the first (D) days of reproduction (Wyatt \& White, 1977).

Effect of two fungi on individual aphids

The first experiment demonstrated that the fungi, individually, had a greater local than systemic effect. In the second experiment this local effect was investigated in more detail, and the effect of the two pathogens combined, either applied at the same time or 5 days apart was studied. Thus, 24- day-old $V$. faba seedlings were inoculated with B. cinerea and $U$. viciae-fabae singly or together on two leaflets of leaf 3, as described above. When 29 days old, further seedlings (and some already infected, depending on treatment) were also infected 
with the two fungi singly and together. This gave the range of treatments illustrated in Figure 2 ( $n=20$ for all treatments), encompassing single infection of both fungi at both times (24 and 29 days), sequential infection (with 5 days gap) of B. cinerea followed by $U$. viciae-fabae and vice-versa, and simultaneous infection by both fungi on both infection days. When the plants were 36 days old, one aphid was caged on an infected leaflet of leaf 3 , as described above, and growth and fecundity parameters were recorded. The number of $B$. cinerea lesions was recorded per $\mathrm{cm}^{2} 10$ days after inoculation and the number of $U$. viciae-fabae pustules 11 days post inoculation.

Effect of one fungus on aphid populations

Individual seeds of $V . f a b a$ were planted in $13.5 \mathrm{~cm}$ diameter plastic pots filled with John Innes II potting compost, and raised in the CE room as above. To assess the effect of singlefungus infection on aphid population development $45 \mathrm{~V}$. faba plants were inoculated 4 weeks after germination (when the fifth leaf had appeared) with $B$. cinerea on all leaves as described above and 45 control plants were sprayed with distilled water. Four days after inoculation four newly-moulted adult $A$. fabae from the stock population were confined in a clip cage on each plant for 24 hours and allowed to reproduce. Five of the resulting offspring were retained on each plant; the mothers and any other offspring were removed, along with the clip-cages. The plants were covered individually with perforated plastic bags (as used in Keary \& Hatcher, 2004). A preliminary experiment (data not shown) demonstrated that the bags prevented aphids from escaping and did not inhibit plant or aphid development in our CE room conditions. Plants were placed in the CE room with treatments randomised, and at 3,4 , and 5 weeks after inoculation a subset of 15 inoculated and 15 control plants were randomly selected and destructively harvested, removing all aphids. The aphids were 
counted, dried at $80^{\circ} \mathrm{C}$ to constant weight and weighed on an electrical microbalance (Sartorius Supermicro S4). The experiment was repeated using the same number of replicates with all leaves of infected plants inoculated with $U$. viciae-fabae spore suspension as above.

Nitrogen analysis

Vicia faba seedlings were raised as before in the growth room. At 4 weeks after germination (when the fifth leaf had emerged), a leaflet on leaf 3 was inoculated with $B$. cinerea and $U$. viciae-fabae, singly and in combination, as given in Figure 5. Two days after inoculation (for B. cinerea) and 10 days after inoculation (for U. viciae-fabae) infected leaflets were removed, oven-dried for 24 hours at $70^{\circ} \mathrm{C}$, milled to a fine powder, and weighed (7-8 mg / sample). Percentage total nitrogen was determined by the Department of Soil Science at University of Reading, using the Roboprep /VG 622 system (Europa Scientific).

Statistical analyses

Three measurements, maturation time, fecundity and $r_{m}$ required that the aphid survived until the end of the experiment. Unfortunately, a few aphid replicates died before the 10 day count of fecundity was over. Hence, analyses of variance for completely randomised designs were carried out using Genstat (version 8) (Lawes Agricultural Trust), since this was able to accommodate treatments having an unequal number of replicates. The effect of a single fungus on individual aphids was analysed by two-factor ANOVA with an added 'control': local infection (aphids reared on the leaflet from leaf 3 ('old') infected with fungus), with two systemic 'treatment' factors age of leaflet (old and young) x presence or absence of infection by $B$. cinerea or $U$. viciae-fabae. In this ANOVA design the factorial treatment structure age 
$\mathrm{X}$ infection is nested within the factor control vs treatment (convstrt); the overall difference between control and treatment (i.e. between local infection and systemic or no infection) is calculated first and then the factorial effects of age and infection are calculated within this nested structure (Stern et al., 2001).

The effect of two fungi on individual aphids was analysed by two-factor ANOVA with factors presence of $B$. cinerea x presence of $U$. viciae-fabae. Each factor had three possible values: absence; presence at time 1 (24-day-old plant); or presence at time 2 (29day-old plant), giving a $3 \times 3$ structure with 9 treatment groups. The number of lesions of $B$. cinerea and number of pustules of $U$. viciae-fabae were log transformed to meet the assumptions of ANOVA. Simple linear regression analysis was performed using Genstat (version 8.0) to determine the effect of the log number of lesions of B. cinerea and the log number of pustules of $U$. viciae-fabae on the mean relative growth rate (MRGR) of $A$. fabae.

Repeated-measurements ANOVA (Genstat version 8.0) was used to determine the effect of inoculation with $B$. cinerea and $U$. viciae-fabae on the population size and dry weight of $A$. fabae 3,4 , and 5 weeks after inoculations, compared to healthy plants.

Percentage nitrogen was analysed by a one-factor ANOVA (Genstat version 8.0).

\section{Results}

Aphis fabae feeding on Botrytis cinerea-infected Vicia faba leaflets had a slower growth rate (3 days longer maturation time and an almost 50\% reduction in MRGR), a 65\% reduction in fecundity and a halved $\mathrm{r}_{\mathrm{m}}$ compared to aphids feeding on similar-aged leaflets on uninfected plants (Figure 1, Table 1). There was a lesser, but still significant systemic effect, with aphids reared on both young and old uninfected leaflets on infected plants having a $24 \%$ 
reduction in MRGR, $35 \%$ reduction in fecundity and a $21 \%$ reduction in $\mathrm{r}_{\mathrm{m}}$ compared to aphids reared on similar-aged leaflets on uninfected plants. There was less effect of leaf age on aphid performance, although aphids developed faster and had a higher $r_{m}$ on younger rather than older leaflets (Figure 1).

Aphids feeding on Uromyces viciae-fabae infected leaflets, by contrast, had an improved performance compared to those reared on similar-aged leaflets on uninfected plants: maturation time was shortened by 2 days, MRGR was increased by $25 \%$, fecundity by $39 \%$ and $r_{m}$ was increased by $48 \%$ (Figure 1). No systemic effect of rust infection was observed, nor did leaflet age have an effect on aphid performance (Table 1).

The combined infection experiment (Figure 2) was concerned with local rather than systemic effects. The effects of $B$. cinerea or $U$. viciae-fabae infection alone mirrored that found in the first experiment, with $B$. cinerea reducing performance and $U$. viciae-fabae increasing it (Figure 2, Table 2), so that aphids feeding on rust-infected leaflets had a 3.5fold greater fecundity and over $100 \%$ increase in $r_{m}$ compared to those reared on $B$. cinereainfected plants. When both fungi were applied simultaneously to a leaflet they generally cancelled the effect of each other out, resulting in most performance parameters similar to the controls, although combined infection reduced fecundity by a third (Figure 2). Sequential infection, (with infection by the second fungus five days after the first) led to a reduction in performance compared to the controls; increasing maturation time, a $70 \%$ decrease in fecundity and 50\% reduction in $\mathrm{r}_{\mathrm{m}}$. The application of rust before botrytis had a greater inhibitory effect on aphids than applying botrytis before rust (Figure 2). The inhibitory effect of botrytis and the stimulatory effect of rust varied in linear relation to the lesion or pustule density in this experiment (Figure 3).

Both botrytis and rust infection inhibited the development of aphid populations on $V$. faba (Figure 4, Table 3), with infected plants having smaller populations of smaller aphids. 
Botrytis reduced total nitrogen content in $V$. faba leaves by $48 \%$, while rust increased nitrogen concentration by $30 \%$ (Figure 5). Combined infection reduced nitrogen by a similar amount to botrytis infection, and the order of infection did not affect nitrogen concentration.

\section{Discussion}

The results of single plant pathogen infections on individual aphids were consistent between the two experiments (Figures 1,2), but were the opposite of that predicted in the introduction from likely interactions between induced resistance pathways. Rather than the predicted stimulation of Aphis fabae growth and development by Botrytis infection, the aphid had slower growth and lower fecundity when feeding on Botrytis-infected leaves. Likewise, rather than the expected decreased performance of the aphid on Uromyces viciae-fabae infected leaves, the aphid actually had increased performance when feeding on these leaves. These results are, however, consistent with the decreased nitrogen content found in the Botrytis-infected leaves and the increased nitrogen concentration found in the rust-infected leaves (Figure 5): Aphis fabae is sensitive to changes in nitrogen levels in plants (Van Emden, 1966; Jaenike, 1990).

Previous studies have found a varying response of aphids to Botrytis infection. Contrary to our results, Zebitz \& Kehlenbeck (1991) found an increase in aphid performance on B. cinerea-infected Vicia faba, and suggested that this was due to the increased availability of amino acids resulting from the degradation of mesophyll cells in the phloem during pathogen-induced senescence, while Mouttet et al. (2011) found that Rhodobium porosum feeding on rose was negatively affected by Botrytis infection. 
Few studies have investigated the effect of biotrophic pathogens on aphids (Hatcher, 1995; Rostás, 2003), although, similar to our experiment Prüter \& Zebitz (1991) found an increase in Aphis fabae performance when reared on Uromyces viciae-fabae-infected Vicia faba, and this aphid also formed significantly larger colonies on Cirsium arvense plants infected with the rust Puccinia punctiformis (Kluth et al., 2002). By contrast, infection of barley by Erysiphe graminis reduced the weight and fecundity of two aphid species, Sitobion avenae and Metopolophium dirhodium (Pesel \& Poehling, 1988).

The effect of local pathogen infection on aphid performance on Vicia faba is correlated with changes in nitrogen concentration in the leaves following infection (Figure 5). Whilst there is little consistency in whether a plant species will respond to a pathogen by increasing or decreasing leaf nitrogen content (Hatcher ,1995), such changes in leaf nitrogen concentration have been correlated with phytophagous insect performance in several studies (Hatcher, 1995). The amino acid composition of infected leaves can also be altered by fungal infection. Botrytis fabae altered the amino acid profile of Vicia faba (El Beih et al., 1988), and decreases in glutamic acid, aspartic acid and increases in asparagine, glutamine, serine and arginine concentrations were found in peach leaves infected by Sphaerotheca pannosa (Raggi, 1976) and bean plants infected by Uromyces phaseoli (Raggi, 1974). Given that aphids are sensitive to changes in composition of phloem amino acids (Douglas, 2006; Powell et al., 2006) it would be instructive to determine the effect of plant pathogens on these amino acids.

Apart from a change in nitrogen concentration, plant pathogens alter other chemical and physical aspects of leaves; some, such as carbohydrates and water are known to affect insects (Hatcher et al., 1995, 1997). The spore concentration of both pathogens applied to the plants in our experiments was selected to produce a medium-strength infection, but not to cover the whole leaf. The effect of the pathogen on the leaf tends to decrease as distance 
from the pustule increases (Hatcher et al., 1995), and while it is unlikely that aphids, as plant suckers, would feed on the sporulating pustules they would have plenty of undamaged material on which to feed, and thus we suggest that gross morphological changes to the leaf are not responsible for the effects observed on aphid performance.

Although infection with plant pathogens can lead to an alteration in nutrient content in uninfected leaves on the plant, these systemic effects are usually weaker than the local effects (Hatcher et al., 1995; 1997) and are usually observed only when a significant leaf area has been infected (Hatcher, 1995). The infection of only one leaflet of $V$. faba with B. cinerea, however, is unlikely to lead to such changes in the physiology of the plant to account for the systemic effects observed on the aphids (Figure 1), and thus this is likely to be due to induced resistance. Botrytis kills host cells at very early stages of infection and causes extensive tissue death (Govrin \& Levine, 2000; Mengiste, 2012). It is therefore unlikely to activate the hypersensitive response and associated activation of defence responses regulated by the SAdependent pathway, as this would only facilitate infection - as has been demonstrated in Arabidopsis (Veronese et al., 2004). Rather, botrytis infection often induces the JA/ET signalling pathway in plants, which can be an effective defence against infection (Thomma et al., 1998; Ferrari et al., 2003; Glazebrook, 2005; Mengiste, 2012), and is insensitive to SAsignalled induced resistance in Arabidopsis and tobacco (van Loon et al., 2006).

Aphids appear to be able to induce both the SA and JA/ET pathways, can be affected by both (Cooper \& Goggin, 2005; Tjallingii, 2006; Goggin, 2007; Thaler et al., 2010) and the induction of either pathway appears to have a variable effect upon them: aphids both being inhibited by necrotrophic fungus infection (Pratt et al., 1982; Moran, 1998) and stimulated (Prüter \& Zebitz, 1991; Zebitz \& Kehlenbeck, 1991; Johnson et al., 2003), depending on the species. 
Biotrophic pathogens, such as the rust fungus $U$. viciae-fabae, induce the hypersensitive (HR) response by the SA-dependent pathway, leading to the activation of many defence activator genes (Glazebrook, 2005) and the development of necrotic lesions at the sites of pathogen entry. A few days after HR development systemic acquired resistance (SAR) can develop in uninfected parts of the plant, providing long-lasting resistance to a range of pathogens (Glazebrook, 2005; Vlot et al., 2009). This has been confirmed in V. faba where the development and exogenous applications of SA can induce systemic acquired resistance to $U$. viciae-fabae (Sillero et al., 2012). No systemic response of rust infection against A. fabae was observed in this experiment (Figure 1) and the increase in aphid performance on infected leaves is consistent with the increase in nitrogen observed in infected leaves (Figure 5), and has been reported also by Zebitz (1988) in this system. Thus, we can conclude that this aphid shows no evidence of being affected by products of aSAdependent systemic pathway that could be induced by the rust fungus. Furthermore, as the SA and JA pathways are often mutually antagonistic, with the stimulation of one pathway leading to the inhibition of the other (Bostock, 2005; van Loon et al., 2006; RobertSeilaniantz et al., 2011) this suggests that in this experimental system this aphid may induce, and is probably inhibited by, the defence products of the JA pathway (which is likely to be inhibited by rust infection and stimulated by botrytis infection) rather than the SA pathway. Although many aphids have been found to be affected by resistance induced by the SA pathway, some aphids can induce, and are affected by, the producets of the JA-mdiated induced resistance pathway (Cooper \& Goggin 2005; Tjallingii, 2006; Goggin, 2007). However, the primary effect of both pathogens on the aphid seems to be via alteration in nitrogen concentration (Figure 5), supported by the significant positive correlation between pustule density and aphid performance (Figure 3) . 
The first two experiments examined the effects of local (Figures 1,2) and systemic (Figure 1) infection of one leaf per plant on individual aphids. The population experiment (Figure 4) examined the effect of whole-plant infection on the increase in aphid populations. The aphid population that developed on plants infected with either pathogen was significantly smaller (and composed of smaller individuals) than that which developed on the uninfected plants (Figure 4). Whilst this supports the negative effect of botrytis on the individual aphids it may be seen to contradict the positive effect of rust on the aphid observed in our individualaphid experiments. However, both pathogens can significantly reduce the size and yield of $V$. faba (Lapwood et al., 1984; Rashid \& Bernier, 1991; Sahile et al., 2010) and our results suggest that whole-plant infection reduces resource availability for the aphids, and thus lowers the plant's aphid carrying capacity. This was also observed by Prüter \& Zebitz (1991). Furthermore, this experiment highlights the need to examine these interactions at the population level: interactions and mechanisms that may be important at the level of the individual may be unimportant at the population level.

As far as we are aware this is the first experiment in which the indirect effect of the infection of two plant pathogenic fungi together on an insect has been examined. Although the nitrogen concentration of dual-infected plants was as low as that in botrytis-only infected plants, in general the aphids performed better on dual-infected plants (when the two pathogens were applied simultaneously) than when fed on those infected with botrytis alone (Figure 2). Although aphid performance is overall is likely to be inhibited by the lack of nitrogen, if we postulate that these aphids are affected by JA-signalled rather than SAsignalled induced defences, then if the rust infection is able to inactive the JA-signalled defence, as suggested above, then the aphids will be able to perform better than on plants infected with botrytis alone. Further evidence for this hypothesis will be gained from experiments in which the effect of the aphid on the two pathogens and the effect of the 
pathogens on each other are investigated. It is unfortunate that we were unable to measure concentrations of SA and JA in these experiments; this will be needed for confirmation of these effects.

The nature and extent of cross-talk between the signalling pathways depends on the timing and magnitude of their induction (van Loon et al., 2006), and this could be reflected in this experiment. Whether the pathogens were applied together or sequentially did not affect leaf nitrogen content, but it did affect aphid performance with greater inhibition of aphids when the pathogens were applied sequentially rather than at the same time (Figure 2). This suggests that concurrent infection may reduce the cross-talk between defence pathways and thus inhibition of defences effective against aphids.

Further experiments are needed to elucidate the mechanisms for the observed effects in this system, but the results suggest that aphids experience a complex and changing food source, with the possibility of their foodplants being infected by a variety of pathogens with their own widely different individual effects, and also effects from their combinations. The observation that these aphids are both significantly inhibited and also significantly enhanced by leaf pathogen infection raises issues for the control of these three pests of Vicia faba. There is the possibility that control measures against some of these pathogens could lead to a consequent increase or decrease in Aphis fabae performance and ultimately plant yield, and thus careful pest management will be essential. This will be investigated in subsequent experiments.

\section{Acknowledgments}


We thank Elizabeth E Wild for technical assistance throughout this project, Professor Michael Shaw for many useful discussions and the Higher Educational Institute, Qatar, and Qatar University, Doha for funding this study.

\section{References}

Banks CJ \& Macaulay EDM (1964) The feeding, growth and reproduction of Aphis fabae Scop. on Vicia faba under experimental conditions. Annals of Applied Biology 53:229242.

Bostock RM (2005) Signal crosstalk and induced resistance: straddling the line between cost and benefit. Annual Review of Phytopathology 43:545-580.

Choquer M, Fournier E, Kunz C, Levis C \& Pradier JM (2007) Botrytis cinerea virulence factors: new insights into a necrotrophic and polyphagous pathogen. FEMS 277:1-10.

Cooper WR \& Goggin FL (2005) Effects of jasmonate-induced defences in tomato on the potato aphid, Macrosiphum euphorbiae. Entomologia Experimentalis et Applicata 115: 107-115.

Davidson JA, Pande S, Bretag TW, Lindbeck KD \& Krishna-Kishore G (2004) Biology and management of Botrytis spp. in legume crops. Botrytis: Biology, Pathology and Control. (ed. by Y Elad, B Williamson, P Tudzynski \& N Delen N) Kluwer, Dordrecht, pp. 295318.

Douglas AE (2006) Phloem-sap feeding by animals: problems and solutions. Journal of Experimental Botany 57: 747-754. 
El Beih FM, Shady MRA, Youssef KA, Kader AIA (1988) Changes in amino acid and sugar content of broad bean leaves following infection with Botrytis fabae. Phytologia 64: 367-378.

Farrar JF \& Lewis DH (1987) Nutrient relations in biotrophic infections. Fungal Infection of Plants (ed. by GF Pegg \& PG Ayres) Cambridge University Press, Cambridge, pp. 92132.

Ferrari S, Plotnikova JM, De Lorenzo G \& Ausubel FM (2003) Arabidopsis local resistance to Botrytis cinerea involves salicylic acid and camalexin and requires EDS4 and PAD2 but not SID2, EDS5 or PAD4. Plant Journal 35:193-205.

Gaunt RE (1983) Shoot diseases caused by fungal pathogens. The Faba Bean (ed. by PD Hebblethwaite) Butterworths, London, pp. 464-473.

Glazebrook J (2005) Contrasting mechanisms of defense against biotrophic and necrotrophic pathogens. Annual Review of Phytopathology 43:205-227.

Goggin FL (2007) Plant-aphid interactions: molecular and ecological perspectives. Current Opinion in Plant Biology 10:399-408.

Govrin EM \& Levine A (2000) The hypersensitive response facilitates plant infection by the necrotrophic pathogen Botrytis cinerea. Current Opinion in Plant Biology 10:751-757.

Grueber K \& Dixon AFG (1988) The effect of nutrient stress on development and reproduction in aphids. Entomologia Experimentalis et Applicata 47:23-30.

Hatcher PE (1995) Three-way interactions between plant pathogenic fungi, herbivorous insects and their host plants. Biological Reviews 70:639-694.

Hatcher PE, Moore J, Taylor JE, Tinney GW \& Paul ND (2004) Phytohormones and plantherbivore-pathogen interactions: integrating the molecular with the ecological. Ecology 85:59-69. 
Hatcher PE, Paul ND, Ayres PG \& Whittaker JB (1995) Interactions between Rumex spp., herbivores and a rust fungus: the effect of Uromyces rumicis infection on leaf nutritional quality. Functional Ecology 9: 97-105.

Hatcher PE, Paul ND, Ayres PG \& Whittaker JB (1997) The effect of nitrogen fertilization and rust fungus infection, singly and combined, on the leaf chemical composition of Rumex obtusifolius. Functional Ecology 11: 545-553.

Hawksworth DL (1991) The fungal dimension of biodiversity: magnitude, significance, and conservation. Mycological Research 95:641-655.

Jaenike J (1990) Host specialization in phytophagous insects. Annual Review of Ecology and Systematics 21:243-274.

Johnson SN, Mayhew PJ, Douglas AE \& Hartley SE (2003) Microbial impacts on plantherbivore interactions: the indirect effects of a birch pathogen on a birch aphid. Oecologia 134:388-396.

Keary IP \& Hatcher PE (2004) Combining competition from Lolium perenne and an insectfungus combination to control Rumex obtusifolius seedlings. Weed Research 44:33-41.

Kluth S, Kruess A \& Tscharntke T (2002) Insects as vectors of plant pathogens: mutualistic and antagonistic interactions. Oecologia 133:193-199.

Lapwood DH, Bainbridge A, McEwen J \& Yeoman DP (1984) An effect of rust (Uromyces viciae-fabae) on the yield of spring-sown field beans (Vicia faba) in the UK. Crop Protection 3:193-198.

Mattson WJ (1980) Herbivory in relation to plant nitrogen content. Annual Review of Ecology and Systematics 11:119-161.

Mengiste T (2012) Plant immunity to necrotrophs. Annual Review of Phytopathology 50:267-294. 
Moran P (1998) Plant-mediated interactions between insects and a fungal pathogen and the role of plant chemical responses to infection. Oecologia 115:523-530.

Mouttet R, Bearez P, Thomas C \& Desneux N (2011) Phytophagous arthropods and a pathogen sharing a host plant: evidence for indirect plant-mediated interactions. PLoS ONE e18840.

Pesel E \& Poehling H-M (1988) Zum Einfluss von abiotischen (Wassermangel) und biotischen (echter mehltau, Erisiphe graminis f.sp. tritici) Stressfaktoren auf die Populationsentwicklung der getreideblattläuse Metopolophium dirhodium Wlak. Und Sitobion avenae F. Mitteilungen der Deutschen Gesellschaft für Allgemeine und Angewandte Entomologie 6: 531-536.

Powell G, Tosh CR \& Hardie J (2006) Host plant selection by aphids: behavioural, evolutionary, and applied perspectives. Annual Review of Entomology 51: 309-330.

Pratt RD, Ellsbury MM, Barnett OW \& Knight WE (1982) Interactions of bean yellow mosaic virus and an aphid vector with Phytophthora root diseases in arrowleaf clover. Phytopathology 72:1189-1192.

Prüter C \& Zebitz CPW (1991) Effects of Aphis fabae and Uromyces viciae-fabae on the growth of a susceptible and an aphid resistant cultivar of Vicia faba. Annals of Applied Biology 87:217-232.

Raggi V (1974) Free and protein amino acids in the pustules and surrounding tissues of rusted bean. Phytopathologische Zeitschrift 81:289-300.

Raggi V (1976) Amino acids in mycelium of Sphaerotheca pannosa var. persicae and in the infected and surrounding tissues of peach leaves. Phytopathologia Mediterranea 15:110114.

Rashid KY \& Bernier CC (1991) The effect of rust on yield of faba bean cultivars and slowrusting populations. Canadian Journal of Plant Science 71:967-972. 
Robert-Seilaniantz A, Grant M \& Jones JDG (2011) Hormone crosstalk in plant disease and defense: more than just JASMONATE-SALICYLATE antagonism. Annual Review of Phytopathology 49:317-343.

Rostás M, Simon M \& Hilker M (2003) Ecological cross-effects of induced plant responses towards herbivores and phytopathogenic fungi. Basic and Applied Ecology 4:43-62.

Sahile S, Fininsa C, Sakhuja PK \& Ahmed S (2010) Yield loss of faba bean (Vicia faba) due to chocolate spot (Botrytis fabae) in sole and mixed cropping systems in Ethiopia. Archives of Phytopathology and Plant Protection 43:1144-1159.

Sillero JC, Rojas-Molina MM, Avila CM \& Rubiales D (2012) Induction of systemic acquired resistance against rust, ascochyta blight and broomrape in faba bean by exogenous application of salicylic acid and benzothiadiazole. Crop Protection 34: 65-69.

Stern R, Arnold G, Coe R \& Buysse W (2001) Using GenStat for Windows $5^{\text {th }}$ Edition in Agriculture and Experimental Biology. ICRAF, Nairobi, Kenya.

Stout MJ, Thaler JS \& Thomma BPHJ (2006) Plant-mediated interactions between pathogenic microoganisms and herbivorous arthropods. Annual Review of Entomology 51:663-689.

Thaler JS, Agrawal AA \& Halitschke R (2010) Salicylate-mediated interactions between pathogens and herbivores. Ecology 91:1075-1082.

Thomma BPHJ, Eggermont K, Penninckx IAMA, Maunch-Mani B, Vogelsang R et al. (1998) Separate jasmonate-dependent and salicylate-dependent defense-response pathways in Arabidopsis are essential for resistance to distinct microbial pathogens. Proceedings of the National Academy of Science, USA 95:15107-15111.

Thrower LB \& Thrower SL (1966) The effect of infection with Uromyces fabae on translocation in broad bean. Phytopathology Zeitschrift 57:267-276. 
Tjallingii WF (2006) Salivary secretions by aphids interacting with proteins of phloem wound responses. Journal of Experimental Botany 57:739-745.

Van Emden HF (1966) Studies on the relations of insects and host plants III. A comparison of the reproduction of Brevicoryne brassicae and Myzus persicae (Hemiptera: Aphididae) on Brussels sprout plants supplied with different rates of nitrogen and potassium. Entomologia Experimentalis et Applicata 9:444-460.

Van Emden HF (1969) Plant resistance to Myzus persicae induced by a plant regulator and measured by aphid relative growth rate. Entomologia Experimentalis et Applicata 12: $125-131$.

Van Emden HF (1972) Aphid Technology. Academic Press, London.

Van Kan JA (2006) Licensed to kill: the lifestyle of a necrotrophic plant pathogen. Trends Plant Science 11:247-253.

Van Loon LC, Rep M \& Pieterse CMJ (2006) Significance of inducible defense-related proteins in infected plants. Annual Review of Phytopathology 44:135-162.

Veronese P, Chen X, Bluhm B, Salmeron J, Dietrich R \& Mengiste T (2004) The BOS loci of Arabidopsis are required for resistance to Botrytis cinerea infection. Plant Journal 40:558-574.

Vlot AC, Dempsey D’MA \& Klessig DF (2009) Salicylic acid, a multifaceted hormone to combat disease. Annual Review of Phytopathology 47: 177-206.

Walling LL (2008) Avoiding effective defenses: strategies employed by phloem-feeding insects. Plant Physiology 146:859-866.

Wojciechowicz-Zytho E \& Van Emden HF (1995) Are aphid mean relative growth rate and intrinsic rate of increase likely to show a correlation in plant resistance studies? Journal of Applied Entomology 119: 405-409. 
Wyatt IJ \& White PF (1977) Simple estimation of increase rates for aphids and tetranychid mites. Journal of Applied Ecology 14:757-766.

Zebitz CPW (1988) Einfluss von Ackerbohnenrost auf die Qualitat von Vicia faba als Wirt von Aphis fabae. Mededelingen von de Faculteit voor Landbouwwetenschappen Rijksuniversiteit Gent 53/3a:1203-1211.

Zebitz CPW \& Kehlenbeck H (1991) Performance of Aphis fabae on chocolate spot diseaseinfected faba bean plants. Phytoparasitica 19:113-119. 


\section{Table 1}

Statistical analysis of the effect of Botrytis cinerea (A) or Uromyces viciae-fabae (B) on the growth and fecundity of individual Aphis fabae. $\mathrm{n}=23$. ***, $\mathrm{P}<0.001 ; * *, \mathrm{P}<0.01 ; *, \mathrm{P}<0.05$, ns, $\mathrm{P}>0.05$. Two factor ANOVA (age of leaflet $x$ presence/absence of systemic infection; together called 'treatment') with separate 'control' (aphids reared on an infected leaflet of leaf 3). Convstrt $=$ overall difference between 'control' and 'treatment'. See text for further details of analysis.

\section{A}

\begin{tabular}{|c|c|c|c|c|c|}
\hline & & $\begin{array}{l}\text { Maturation time } \\
\text { (days) }\end{array}$ & MRGR & Fecundity & $\mathrm{r}_{\mathrm{m}}$ \\
\hline Source & $\mathrm{df}$ & MS & MS & MS & MS \\
\hline Convstrt & 1 & $46.37 * * *$ & $0.0508 * * *$ & $5279 * * *$ & $0.155 * * *$ \\
\hline $\begin{array}{l}\text { Convstrt x Age } \\
\text { of leaflet }\end{array}$ & 1 & $8.183 * * *$ & $0.0001 \mathrm{~ns}$ & $0.14 \mathrm{~ns}$ & $0.003 * *$ \\
\hline $\begin{array}{l}\text { Convstrt X } \\
\text { Infection }\end{array}$ & 1 & $62.81 * * *$ & $0.0351 * * *$ & $3769 * * *$ & $0.116 * * *$ \\
\hline $\begin{array}{l}\text { Convstrt } x \text { age } \\
x \text { infection }\end{array}$ & 1 & $3.594 * *$ & $0.0001 \mathrm{~ns}$ & $77.26 *$ & $0.0001 \mathrm{~ns}$ \\
\hline Residual & 87 & 0.3537 & 0.0014 & 15.82 & 0.0003 \\
\hline Total & 91 & & & & \\
\hline
\end{tabular}




\begin{tabular}{llllll}
\hline & & $\begin{array}{l}\text { Maturation time } \\
\text { (days) }\end{array}$ & MRGR & Fecundity & $\mathrm{r}_{\mathrm{m}}$ \\
\hline Source & $\mathrm{df}$ & MS & MS & MS & MS \\
\hline Convstrt & 1 & $143.3 * * *$ & $0.0245^{* * *}$ & $2358 * * *$ & $0.2658 * * *$ \\
Convstrt x Age & 1 & $0.141 \mathrm{~ns}$ & $0.0001 \mathrm{~ns}$ & $41.3 \mathrm{~ns}$ & $0.0001 \mathrm{~ns}$ \\
of leaflet & & & & & \\
Convstrt x & 1 & $0.147 \mathrm{~ns}$ & $0.002 \mathrm{~ns}$ & $28.53 \mathrm{~ns}$ & $0.0005 \mathrm{~ns}$ \\
$\begin{array}{l}\text { Infection } \\
\text { Convstrt x Age }\end{array}$ & 1 & $1.356 \mathrm{~ns}$ & & & \\
$\begin{array}{l}\text { X Infection } \\
\text { Residual }\end{array}$ & 112 & 1.100 & $0.008 \mathrm{~ns}$ & $72.80 \mathrm{~ns}$ & $0.0025 \mathrm{~ns}$ \\
Total & 116 & & & 38.89 & 0.0012 \\
\hline
\end{tabular}




\section{Table 2}

Statistical analysis of the effect of Botrytis cinerea or Uromyces viciae-fabae infection, individually or combined on the growth and fecundity of individual Aphis fabae reared on infected leaves. Two-factor ANOVA (infection with $B$. cinerea $\mathrm{x}$ infection with $U$. viciaefabae $) . * * *, \mathrm{P}<0.001$.

\begin{tabular}{|c|c|c|c|c|c|}
\hline & & $\begin{array}{l}\text { Maturation } \\
\text { time }\end{array}$ & MRGR & Fecundity & $\begin{array}{l}\text { Intrinsic rate of } \\
\text { increase }\end{array}$ \\
\hline Source & df & MS & MS & MS & MS \\
\hline Botrytis & 2 & $13.3 * * *$ & $0.01 * * *$ & $369 * * *$ & $0.03 * * *$ \\
\hline Uromyces & 2 & $195 * * *$ & $0.08 * * *$ & $8718 * * *$ & $0.42 * * *$ \\
\hline Botrytis $\mathrm{x}$ & 4 & $28.6 * * *$ & $0.01 * * *$ & $671 * * *$ & $0.049 * * *$ \\
\hline \multicolumn{6}{|l|}{ Uromyces } \\
\hline Residual & 144 & 0.89 & 0.002 & 14.9 & 0.001 \\
\hline Total & 152 & & & & \\
\hline
\end{tabular}




\section{Table 3}

Statistical analysis of the effect of Botrytis cinerea (A) or Uromyces viciae-fabae (B) infection on the population growth of Aphis fabae on Vicia faba. Repeated measures ANOVA calculated. $* * *, \mathrm{P}<0.001$.

A

\begin{tabular}{llll}
\hline & & Number of aphids & Dry weight of aphids \\
\hline Source & df & MS & MS \\
\hline Time after infection & 2 & $8617 * * *$ & $0.278 * * *$ \\
Infection & 1 & $1193 * * *$ & $0.355 * * *$ \\
Time x infection & 2 & $4746 * * *$ & $0.198 * * *$ \\
Residual & 84 & 2713 & 0.002 \\
Total & 89 & & \\
\hline
\end{tabular}

B

Number of aphids $\quad$ Dry weight of aphids

\begin{tabular}{llll}
\hline Source & df & MS & MS
\end{tabular}

\begin{tabular}{lccc}
\hline Time after infection & 2 & $1394 * * *$ & $0.181 * * *$ \\
Infection & 1 & $2595 * * *$ & $0.413 * * *$ \\
Time x infection & 2 & $6631 * * *$ & $0.074 * * *$ \\
Residual & 84 & 2025 & 0.002 \\
Total & 89 & & \\
\hline
\end{tabular}


Figure legends

Figure 1 The local and systemic effect of Botrytis cinerea or Uromyces viciae-fabae infection of Vicia faba on the growth and fecundity of individual Aphis fabae. Means $\pm \mathrm{SE}$ given. See Table 1 for statistical analysis. Solid bar, 'old' infected leaflet (on third leaf); hatched bars, 'old' uninfected leaflet (on third leaf); open bars, 'young' uninfected leaflet (on fifth leaf). Same letters signify no significant difference $(\mathrm{P}>0.05)$ between means, from LSD from ANOVA.

Figure 2 The effect of Botrytis cinerea or Uromyces viciae-fabae infection, individually or combined on the growth and fecundity of individual Aphis fabae reared on infected leaflets. Means \pm SE given, $n=20 . X$-axis legend key: Control, uninfected leaf; $B$, Botrytis infection; R, Uromyces infection; 24 or 29 days after plant germination; thus B24 indicates infected with $B$. cinerea 24 days after germination, and B24R29 indicates infected with B. cinerea 24 days after germination, and infected with $U$. viciae-fabae 5 days later (29 days after germination). Singly-infected leaflets are hatched, doubly-infected leaflets are cross-hatched. Summary results of two-factor ANOVA given (see Table 2 for statistical analysis): B, Botrytis infection; R, Uromyces infection; B x R, interaction term. ***, $\mathrm{P}<0.001$. Same letters signify no significant difference $(\mathrm{P}>0.05)$ between means, from LSD from ANOVA. 
Figure 3 Regression of lesion/pustule density of Botrytis cinerea (A) and Uromyces viciaefabae $(\mathrm{B})$ against aphid mean relative growth rate. $\mathrm{A}, \mathrm{F}_{1,102}=268, \mathrm{P}<0.001, \mathrm{r}^{2}=0.722 . \mathrm{B}, \mathrm{F}$ $1,101=399, \mathrm{P}<0.001, \mathrm{r}^{2}=0.798$

Figure 4 The effect of Botrytis cinerea or Uromyces viciae-fabae infection on the population growth (number and dry weight) of Aphis fabae on Vicia faba. Mean \pm SE given, $=15$. Solid line, uninfected plants; dashed line, infected plants. Summary results from ANOVA (see Table 3 for statistical analysis): I, infection; T, time; I x T, interaction term. ***, $\mathrm{P}<0.001$.

Figure 5 Percentage dry weight nitrogen content of Vicia faba leaves infected with Botrytis cinerea (B) and/or Uromyces viciae-fabae (R), 24 or 29 days after plant germination (see Figure 2 for details). Mean \pm SE given, $n=5$, except for control where $n=2$. Same letters signify no significant difference $(\mathrm{P}>0.05)$ between means, LSD from ANOVA $\left(\mathrm{F}_{5,24}=89.01\right.$, $\mathrm{P}<0.001)$. 
Fig. 1

Botrytis
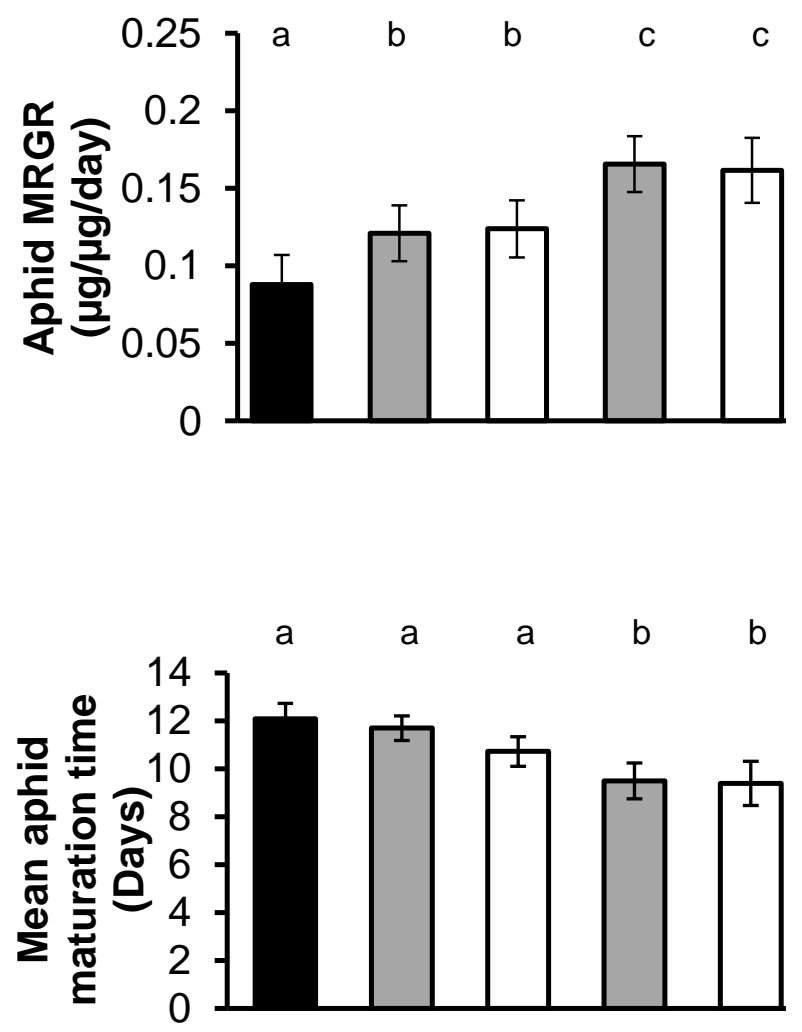

\section{Uromyces}

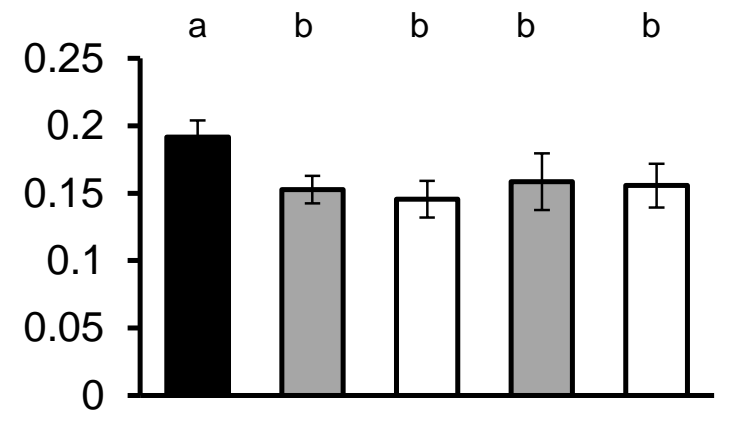

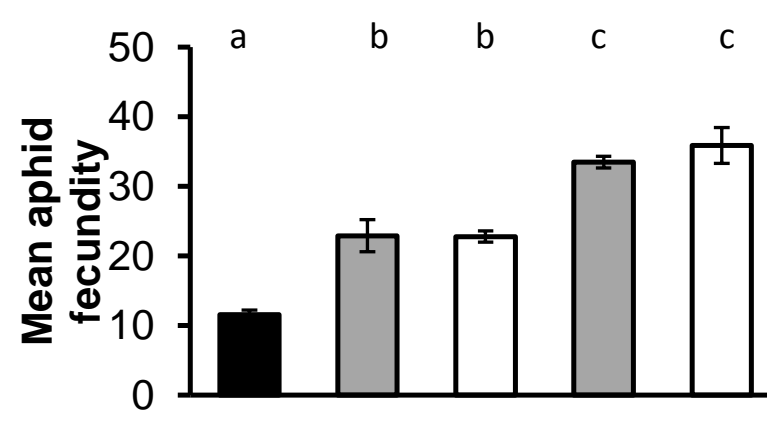
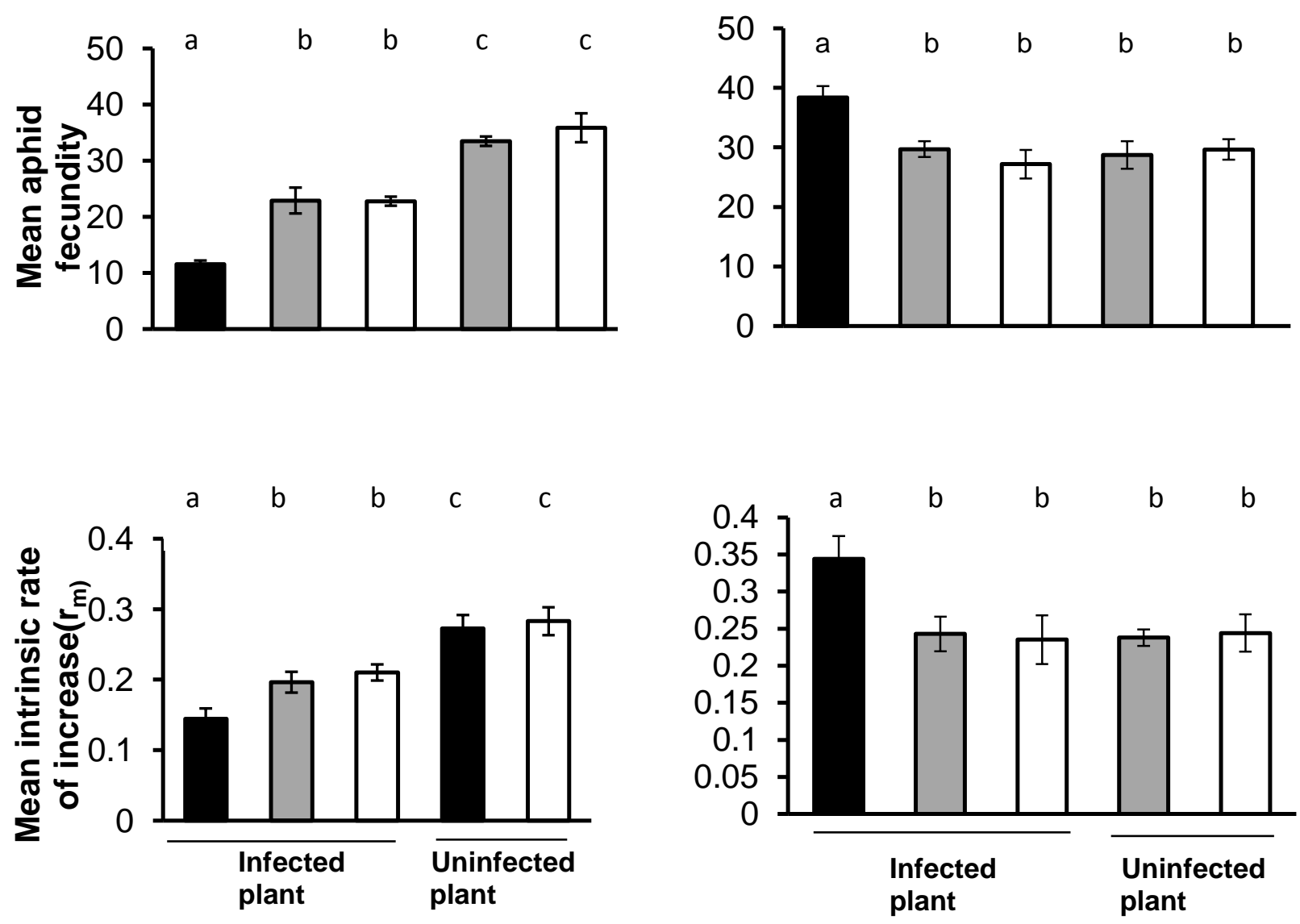
Fig 2

$$
\mathrm{B} * * *, \mathrm{R} * * *, \mathrm{~B} \times \mathrm{R} * * *
$$

$\begin{array}{lllllllll}a & b & b & c & c & a & a & b & b\end{array}$
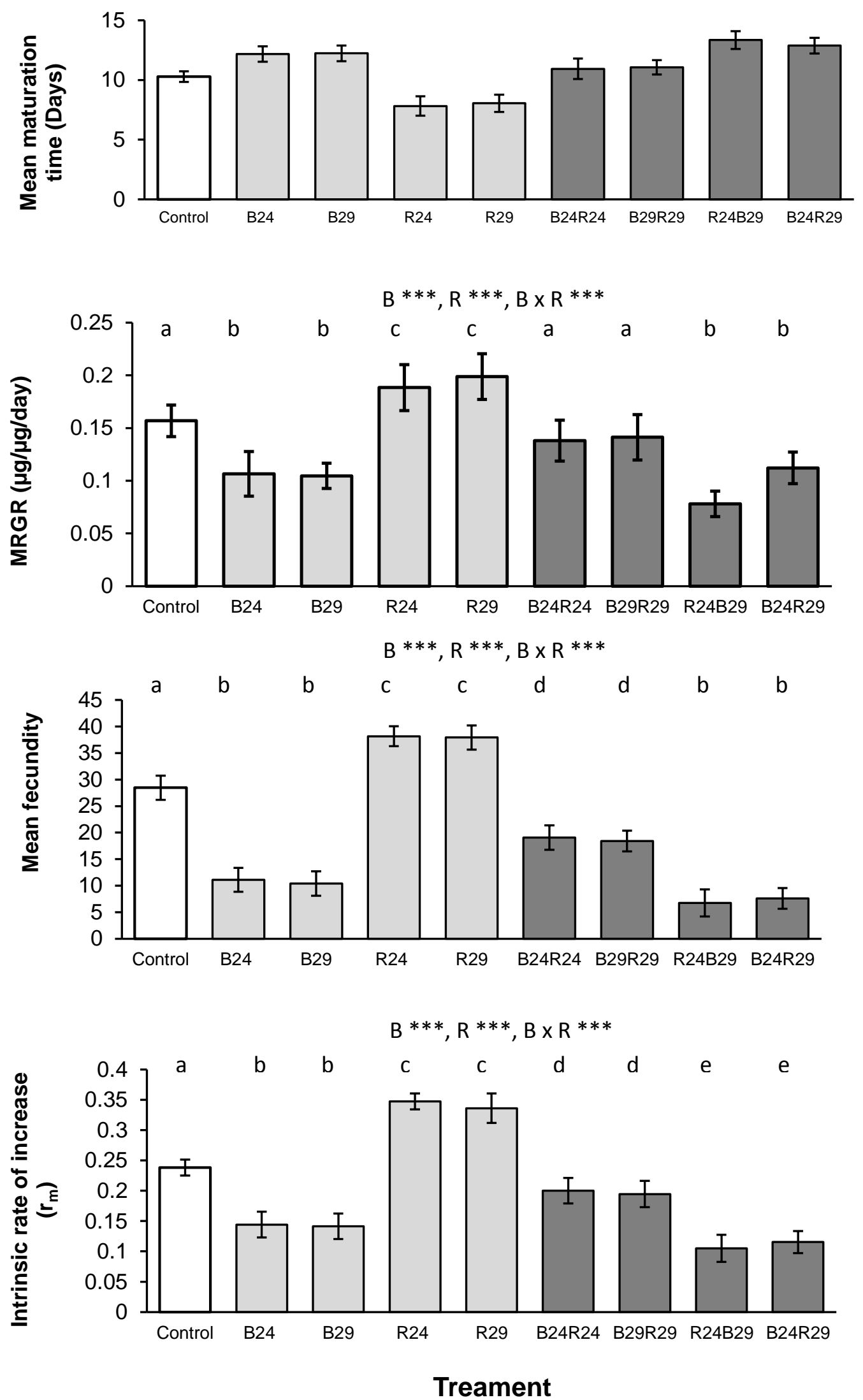
Fig 3

A

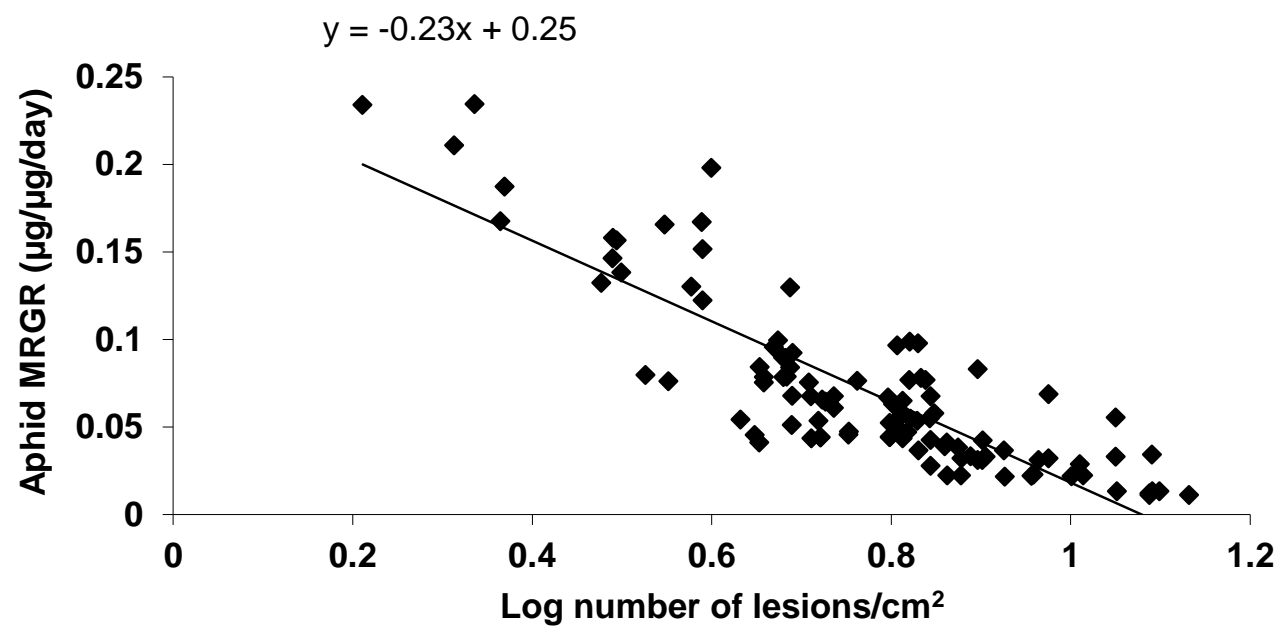

B

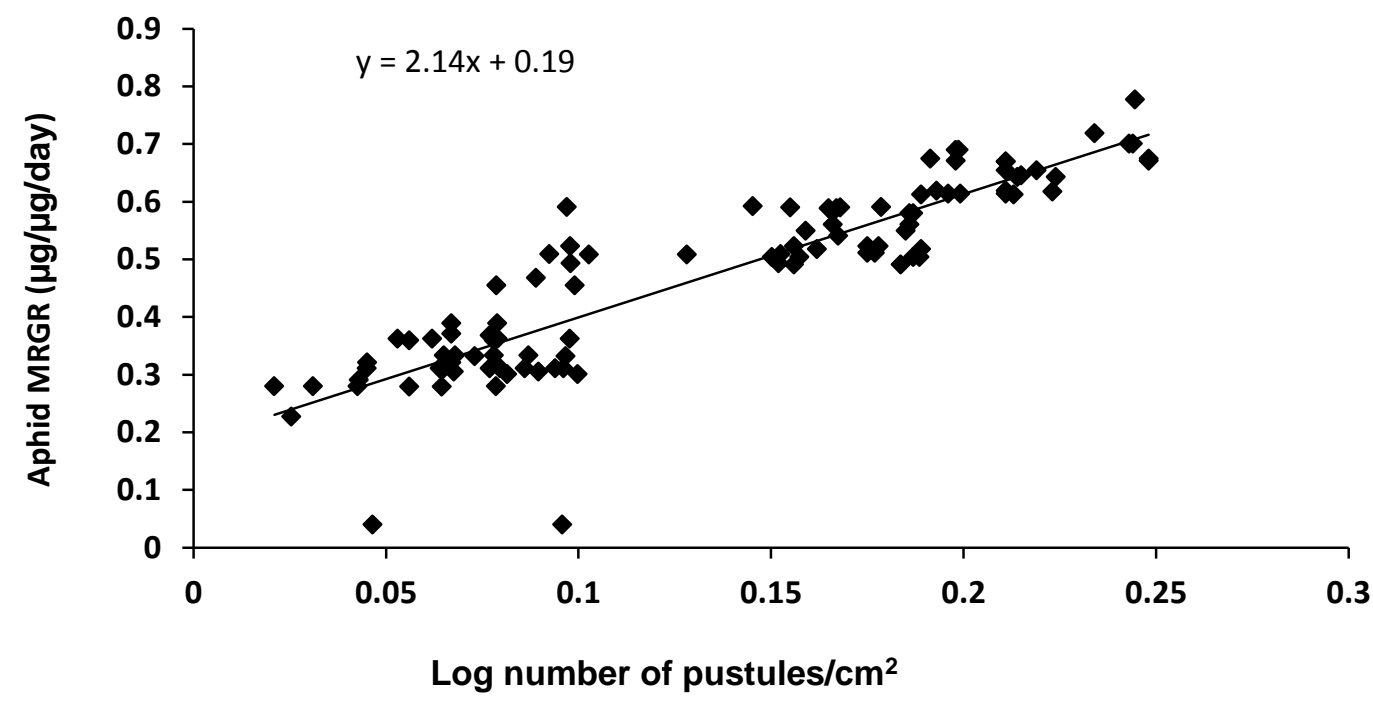


Fig 4

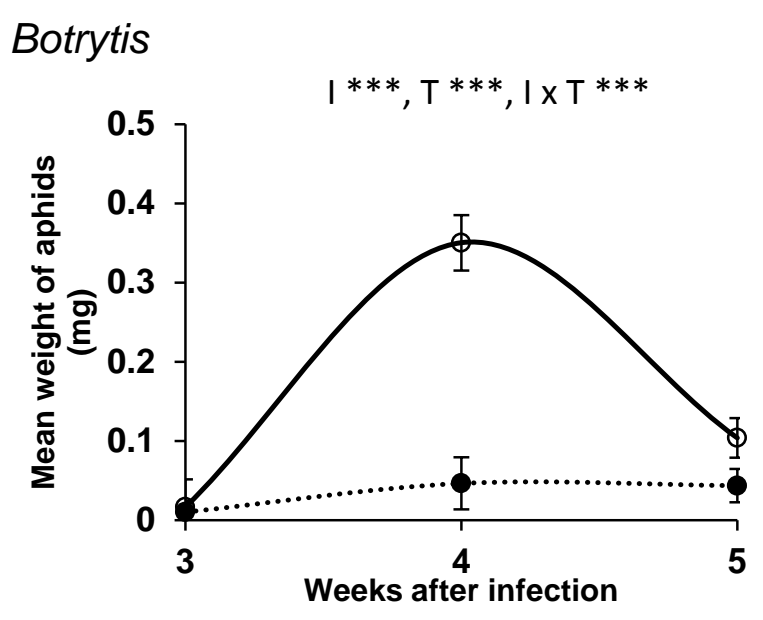

Uromyces
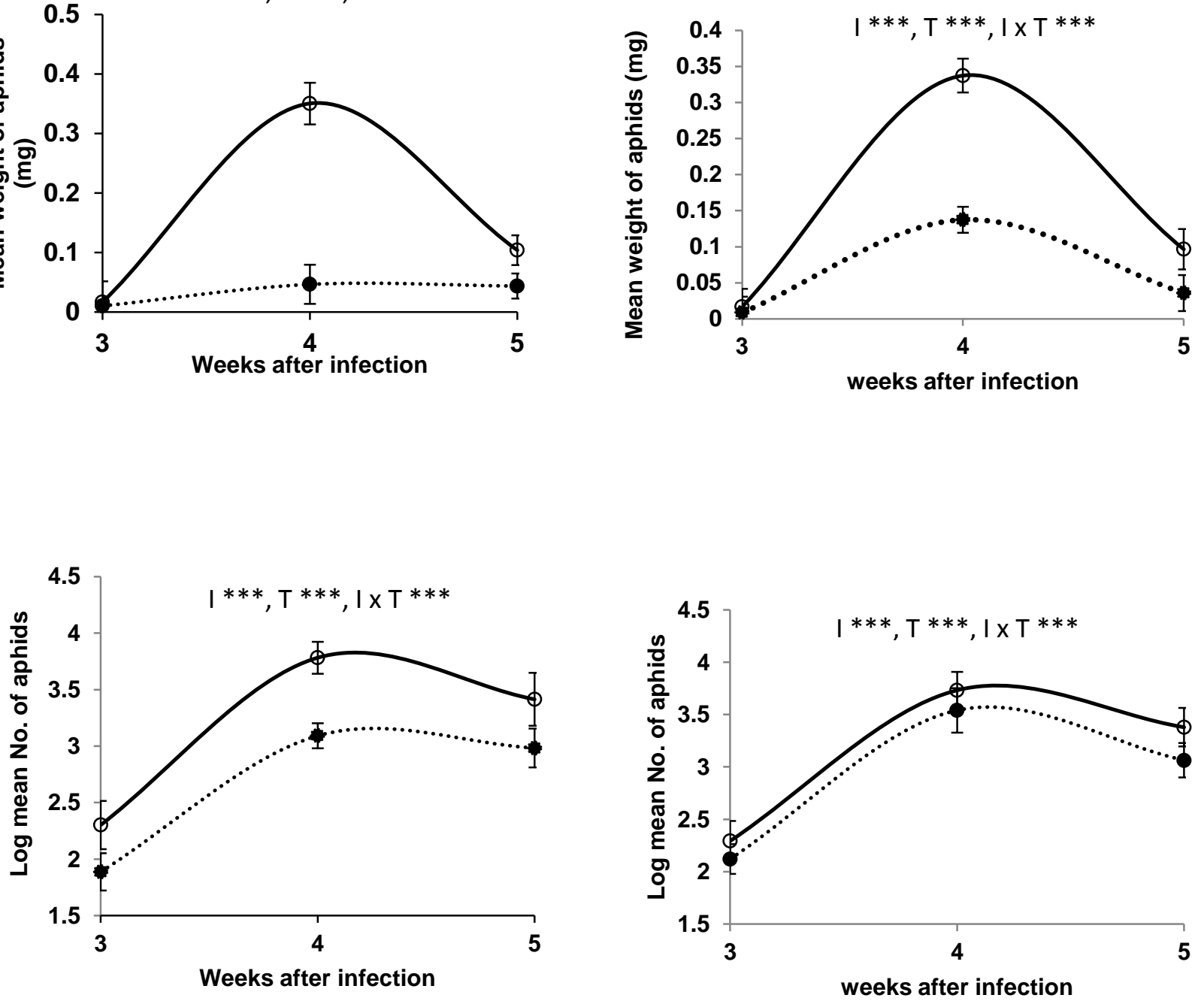
Fig 5

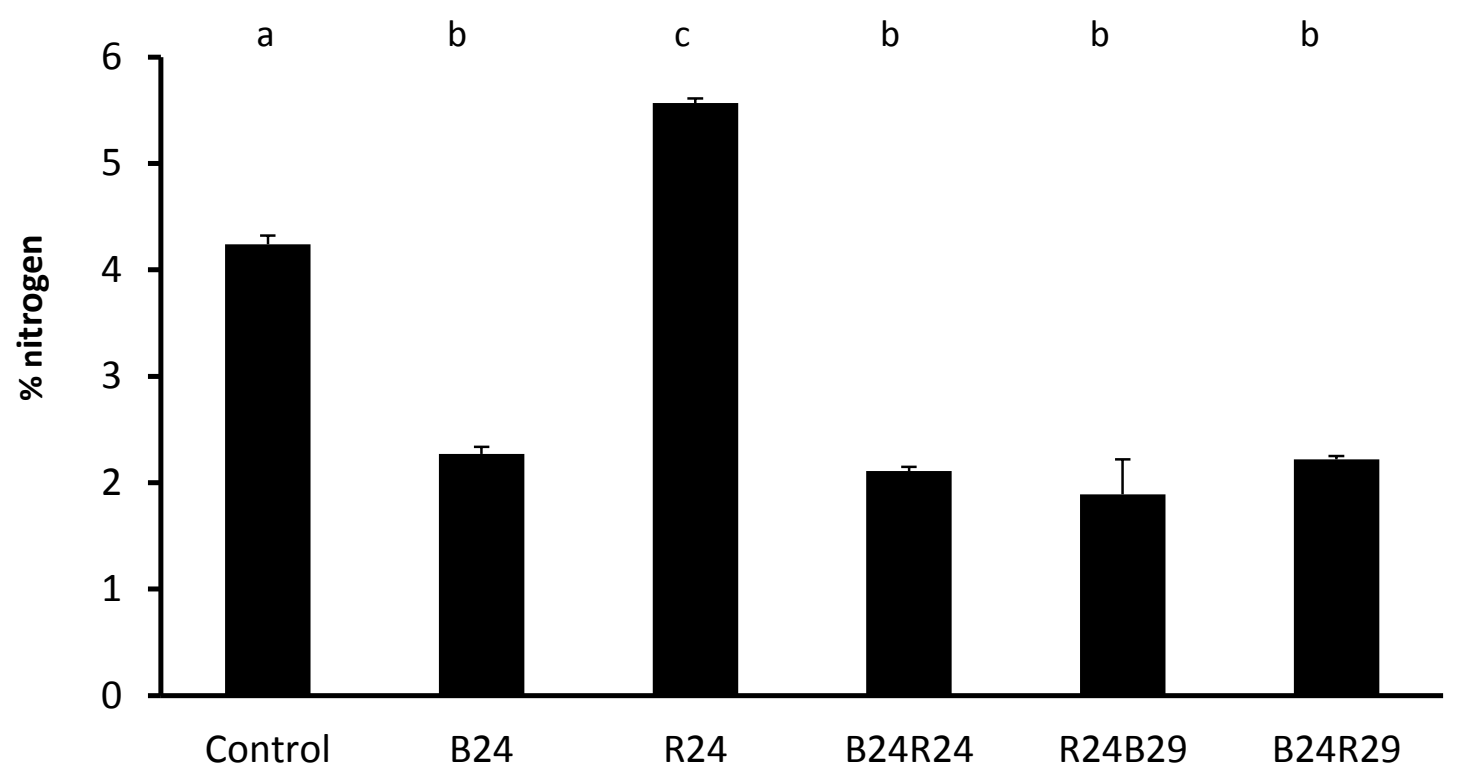

